\title{
First Report of Leaf Spot of Strawberry Caused by Alternaria tenuissima in Iran
}

\author{
Shima Bagherabadi, Doustmorad Zafari* and Mohammad Javad Soleimani
}

Department of Plant Protection, College of Agriculture, University of Bu Ali Sina, Hamedan, Iran

\begin{abstract}
During a survey in autumn of 2013, leaf spots symptoms on strawberry (Fragaria ananassa) leaves were observed in Kurdistan province, Iran. From symptomatic leaves cultured on PDA medium totally 24 isolates of Alternaria were obtained. According to morphological and molecular studies obtained isolates were identified as $A$. tenuissima. To our knowledge, this is the first report of $A$. tenuissima on strawberry in Iran.
\end{abstract}

Keywords: Fragaria ananassa; Alternaria; Kurdistan province

\section{Short Communication}

The latest statistics by Iran ministry of agriculture shows about 2113 hectare of lands in the Kurdistan province is allocated for production of strawberry and annual production is estimated about 21130 ton. During a survey in autumn of 2013, leaf spots symptoms on strawberry leaves were observed in Kurdistan province, Iran (Figure 1A) with all major growing areas of the province affected. Disease incidence exceeded $50 \%$ in some regions in severely infected fields. Symptoms were further monitored on 35 selected plants. Initially, symptoms appeared on leaves as small, yellowish brown spots, becoming brown and finally necrotic with age. Small symptomatic leave fragments were cut from healthy sections and were placed on Potato Dextrose Agar (PDA). Petri dishes were kept in an incubator at $25^{\circ} \mathrm{C}$. Five to seven days after incubation, totally 24 Alternaria isolates were obtained from the strawberry symptomatic leaves in the growing areas. Obtained isolates after purification using single spore method were transferred to petri dishes containing Potato Carrot Agar (PCA) to study the morphological characteristics in an attempt to identify the cultures to species levels, These petri dishes were kept at $23-25^{\circ} \mathrm{C}$ under fluorescent light with light cycle of 8 hours light and 16 hours dark and were studied after five to seven days. Isolates on PCA medium, were brownish green and formed concentric rings, loosely cottony. The light exposed rings of colonies are dominated at $4 \mathrm{~d}$ by unbranched chains of 6-10 conidia. Longer chains and uncommon branching were found in colonies aging past $7 \mathrm{~d}$. Mature conidia have only transepta reach size range 30-40 $\times$ 10-13 $\mu \mathrm{m}$, ovoid, these median constricted conidia may be ovoid with a short apical secondary conidiophore. Muriformly septate conidia 32-40 $\times 14-16 \mu \mathrm{m}$. Conidia are median brown in color and rarely punctulate in ornamention with 2-7 transverse and 1-2 longitudinal septa (Figure 1B-1E). Microscopic identification was achieved using Lica DMLB microscope. Based on morphological characteristics, the pathogen was identified as Alternaria tenuissima [1]. To confirm the morphological identification, molecular identification was conducted based on
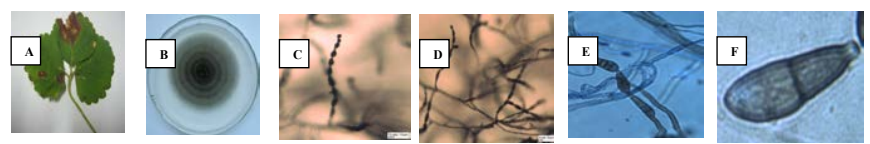

Figure 1: A) Symptoms of leaf spot on Strawberry leaves. B) Surface of colony after 7 days on PCA. C) Simple conidiophore and long conidial chain. D) Branched conidial chain. E) Conidia with a distinct medium septum. F) Distinct and thick medium septum.
DNA sequences of the glyceraldehyde-3-phosphate dehydrogenase gene $(g p d)$ and its sequences was submitted to GenBank (Accession number KP276228). The BLAST similarity search using the sequences of the isolate revealed a high similarity to Alternaria tenuissima with GenBank entries JN634820. In order to confirm Koch's postulates, pathogenicity tests were conducted on strawberry leaves. Strawberry leaves, were sprayed with conidial suspension $\left(10^{6} \mathrm{spores} / \mathrm{ml}\right)$, while control plants were sprayed with sterilized distilled water. After inoculation, leaves were kept in a growth chamber at $25^{\circ} \mathrm{C}$. Leaf spot symptoms were observed on the inoculated leaves after 7 days and $A$. tenuissima was successfully reisolated from artificially infected leaves, while did not appear any spots on the control leaves. A. tenuissima was previously reported on Fragaria ananassa in Florida [2,3] and Korea [4]. To our knowledge, this is the first report of A. tenuissima on Fragaria ananassa (strawberry) in Iran. The culture has been deposited in the Public Collections of the CBS, The Netherlands, with Accession No. CBS (139417).

\section{References}

1. Simmons EG (2007) Alternaria an identification manual fully illustrated and with catalogue raisonne CBS Biodiversity Series No. 6. Published by Utrecht, The Netherlands. CBS Fungal Biodiversity Centre.

2. Alfieri Jr, Langdon SA, Wehlburg KR, Kimbrough JW (1984) Index of Plant Diseases in Florida (Revised). Florida Department of Agriculture and Consumer Services Division of Plant Industry. Bull 11: 1-389.

3. Howard CM, Albregts EE (1973) A strawberry fruit rot caused by Alternaria tenuissima. Phytopathology 63: 938-939.

4. Cho WD, Shin HD (2004) List of plant diseases in Korea, 4th edn. Suwon Korea: The Korean Society of Plant Pathology.

*Corresponding author: Doustmorad Zafari, Department of Plant Protection College of Agriculture, University of $\mathrm{Bu}$ Ali Sina, Hamedan, Iran, Tel: +989183137285; Fax: +98.8134424190; E-mail: Zafari_d@yahoo.com

Received November 27, 2014; Accepted March 26, 2015; Published March 29 2015

Citation: Bagherabadi S, Zafari D, Soleimani MJ (2015) First Report of Leaf Spot of Strawberry Caused by Alternaria tenuissima in Iran. J Plant Pathol Microb 6: 258. doi:10.4172/2157-7471.1000258

Copyright: ( $\odot 2015$ Bagherabadi S, et al. This is an open-access article distributed under the terms of the Creative Commons Attribution License, which permits unrestricted use, distribution, and reproduction in any medium, provided the original author and source are credited. 